Article

\title{
Application of an Integrated Assessment Scheme for Sustainable Waste Management of Electrical and Electronic Equipment: The Case of Ghana
}

\author{
Mentore Vaccari ${ }^{1, *(D)}$, Fabiola Zambetti ${ }^{1}$, Margaret Bates ${ }^{2}$, Terry Tudor ${ }^{2}$ and Teklit Ambaye ${ }^{1}(\mathbb{D}$ \\ 1 CeTAmb LAB - Research Laboratory on Appropriate Technologies for Environmental Management in \\ resource-limited Countries, University of Brescia, via Branze 43, 25123 Brescia, Italy; \\ f.zambetti001@unibs.it (F.Z.); t.ambaye@unibs.it (T.A.) \\ 2 Faculty of Arts, Science, and Technology, the University of Northampton, Waterside Campus, \\ University Drive, Northampton NN1 5PH, UK; margaret.bates@northampton.ac.uk (M.B.); \\ terryl.tudor@gmail.com (T.T.) \\ * Correspondence: mentore.vaccari@unibs.it
}

Received: 6 March 2020; Accepted: 10 April 2020; Published: 15 April 2020

\begin{abstract}
The effective management of solid waste, including waste electrical and electronic equipment (WEEE) in developing countries poses significant challenges. This paper reports on the development and utilization of a multi-criteria tool to improve the management of WEEE in Agbogbloshie, in Ghana. The tool was able to successfully evaluate key economic, social and environmental factors faced by workers and to suggest areas for improvement. In particular, the evaluation and comparison of different scenarios suggested that the best solution is the evolution from informal to formal management of WEEE, with workers provided with personal protective equipment, and the introduction of refurbishment activities, with the sale of components in the second-hand market. While it would require further use in other contexts, the tool could be adapted and employed for a range of other waste streams and in other developing countries.
\end{abstract}

Keywords: developing countries; e-waste; material flow analysis; participatory approach; sustainability; WEEE

\section{Introduction}

In the past ten years, the manufacture of electrical and electronic equipment (EEE) has increased dramatically due to the growth in the demand for high-tech applications [1-5]. This rise has led to an increase in the quantity of waste electrical and electronic equipment (WEEE) generated. This phenomenon also raises environmental concerns related to the production and use of EEE [6-9]. For example, various studies have suggested that quantities and costs of managing WEEE will rise in years to come [10], leading to significant environmental and social concerns [11]. These potential hazards therefore necessitate the need for urgent action in order to reduce the public health and environmental risks faced, particularly in developing countries [12-22]. However, at the same time, WEEE also contains a number of valuable materials, including metals, plastics, and rare earth metals such as europium, terbium, yttrium, cerium, gadolinium and neodymium [23,24]. Therefore, it is important also for there to be systems put in place to effectively recover the inherent value contained in the WEEE through, for example, recycling, reuse and remanufacturing $[25,26]$.

\subsection{Risks Posed from Managing WEEE in Ghana}

One of the developing countries, which has put strategies in place to address the risks posed by WEEE and to recover value from the waste, is Ghana. In 2016, Ghana issued the Presidential 
Decree (Act 917)/2016 for the Hazardous and Electronic Waste Control and Management to facilitate the development of a novel and innovative approach for the sustainable management of WEEE in the country. The main objective of the Decree was to reduce and prevent the generation of the WEEE. It also aimed to reduce the risks posed through a collaborative approach involving all key stakeholders (e.g., scientists, civil society organizations, industry, and policy-makers) [27,28]. However, Baldé et al. [10] found that only about $0.5 \%$ of the WEEE was being collected and managed effectively in Ghana.

Thus, despite the introduction of the legislation, urgent action is required to address and improve the existing practices. Indeed, procedures adopted by WEEE recyclers in developing countries such as Ghana, present significant risks to human health and contamination by hazardous chemicals to the environment. The release of hazardous substances such as arsenic, lead, dioxins, mercury, furans, and brominated flame retardants during the informal processing of WEEE, is often absorbed by workers or deposited on food in the markets. Exposure to these hazardous chemicals has been shown to be harmful both to children and adults, with children being the most vulnerable to the risks [29]. During the development of the strategies, all the stakeholders involved in the system should always be included, and each of the sustainability pillars (i.e., social, economic and environmental factors) should be considered, as highlighted by the Integrated Solid Waste Management (ISWM) concept [30].

Using Ghana as the case study country, this study reports on the development and evaluation of a scenario-based framework called E-Waste Integrated Assessment Scheme (EWIAS) to evaluate the most effective approach to minimize risk, and recover value from WEEE. EWIAS is based on performance criteria regarding economic, social and environmental dimensions.

\subsection{The Case Study Area}

The study was conducted in a suburb in Accra (the capital city of Ghana), called Agbogbloshie, which has an area of 146.21 ha and is less than $1 \mathrm{~km}$ from the capital city. The site has existed for some time as a disposal site for WEEE and household waste, and in 1994, the scrap dealers located there registered as the Scrap Dealers' Association of Ghana [31].

Agbogbloshie is a formal human settlement, surrounded by informal residential developments. It, thus, has a mix of commercial and residential functions and contains a large number of markets and a variety of small economic enterprises including the WEEE chain of activities. At the time of the study, it was the largest WEEE processing site in Ghana, with several tons of WEEE disposed of on a daily basis. These WEEE are then dismantled to extract copper and other valuable fractions. It is estimated that about 100 million computer waste items are scrapped at the site annually [32]. The burning of sheathed cables and the resulting toxic emissions into the atmosphere is a major concern [33]. At the time of the study, it was estimated that in Agbogbloshie, there were at least 100 treatment workshops managing WEEE [34].

Profit was made from the sale of valuable materials, mainly copper. Some other electronic parts (e.g., PCBs) were also sold for a profit. Some of the copper was produced by the burning of cables. In Agbogbloshie, there was a specific area where young men, between 14 - 18 years old, ran the cable burning activities. The copper produced by burning had a lower quality (B grade) than the copper mechanically extracted. However, extraction of the copper by burning the cable was cheaper.

Despite the varied age group, the workforce at the site was comprised of mostly young people between the ages of 15 - 35 years. Caravanos et al. [33] identified children as young as 11 years. Manhart et al. [35] and Amoyaw-Osei et al. [32] showed that WEEE and scrap waste processing, as well as foodstuff trading, were the main occupations in Agbogbloshie. Manhart et al. [35] estimated that there are close to 200,000 persons dependent on WEEE recycling activities. 


\section{Materials and Methods}

\subsection{The Scenarios Analyzed}

The research was undertaken in 2017 and analyzed six different scenarios of WEEE management in Agbogbloshie. The functional unit was a single workshop. At the time of the study, an average workshop received and treated a mixture of WEEE (e.g., desktop computers, laptops, printers or parts of printers, small engines, pre-treated WEEE parts, etc.). The area of the workshop was around $50 \times 10 \mathrm{~m}^{2}$ and it was covered by a metal projecting roof, with the remaining area being exposed. All of the activities were carried out on an unpaved floor. The workshop had a scale for weighing. During the onsite visits, the team leader indicated that $525 \mathrm{~kg} / \mathrm{d}$ of WEEE was managed, on average, in the workshop. However, no information was provided on the quantities of recyclables recovered and sold, thus, they were estimated from the literature (see Supplementary Material SM-B).

A total of six scenarios (G0 - G5) were developed and evaluated. The scenarios introduced step by step technical improvements to enhance the existing practices. It is important to note that for simplicity, each scenario considered a single workshop only. Based on previous studies, the scenarios employed a holistic approach incorporating quantitative and qualitative data, and took account of social, environmental and economic factors [36-42]

The baseline scenario (G0) reflected the existing situation of informal WEEE management in the workshop. There were five workers, who worked six days per week. The workers were all young men aged between 16 and 30 years old. There was one team leader aged around 30 years old. WEEE was dismantled in the scrapyard using basic tools like hammers and screwdrivers. There were no desks or suitable personal protective equipment (PPE) used. Figure 1 shows the undertaking of manual dismantling in the workshop.
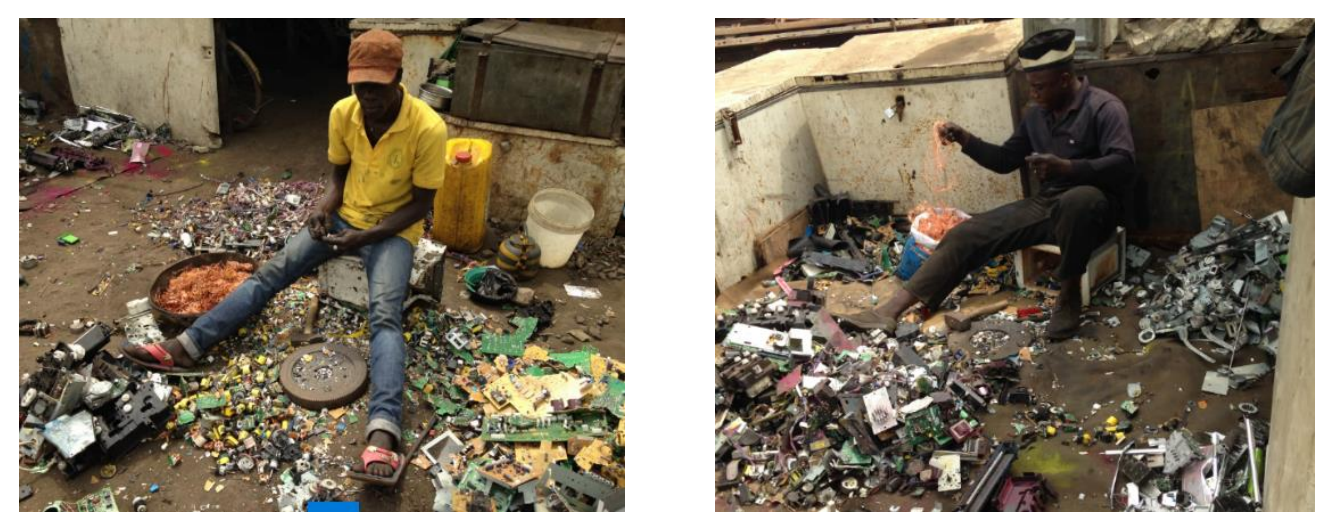

Figure 1. Dismantling activities in the case study waste electrical and electronic equipment workshop.

It is important to underline that in scenario G0, the costs of disposing of the discarded components were not considered, because none of the valuable extracted components were dumped or burnt.

Scenario G1 represents the first upgrade of G0. The main objective of this scenario was to substitute the open burning of cables for a simple and cheap technology, like a manual cable stripper. However, the machine cannot strip all kinds of cables, because it is not able to remove plastic insulation from very thin wires. It was estimated that at least $50 \%$ of the cables in the workshop could be managed using this kind of device and the remaining components of the cables burnt, as in the G0 scenario.

Scenario G2 proposes an alternative solution to avoid the burning of cables, involving the installation of a cable shredder to separate plastics and metals. The process of separation is comprised first of shredding, and the second step, division of the different components based on the physical characteristics of the various materials. In particular, in this scenario, the proposed shredder is "e-source", a pedal-powered cable shredder that reduces the cables into tiny components, and separates the plastic by flotation [43]. 
Scenario G3 denotes a different upgrade to G0 and G1 and is a variation of scenario G2. It considers substitution of the open burning of wire by a more complex technology, namely an electrical cable shredder. The manual wire stripping machine considered in scenario G1 is useful for stripping plastic insulation from thick cables, but is not able to remove plastic from thin wires. A shredding machine can overcome these limitations, but is expensive to purchase. It is also more expensive to use than a manual stripping machine because it needs electricity and higher maintenance. Considering the very high cost of such a device, it was assumed that the shredder is bought by a group of 10 workshops that use it in a cooperative way. Scenario G3, similarly to scenario G2, completely avoids the burning of cables. It could potentially also increase earnings from the sale of copper which is $100 \%$ A grade (highest quality). At the time of the study, there was no market for plastics obtained by shredding, however, the sale of these materials could create additional revenue in the future. In scenario G3, as in the previous scenarios, the recycling activities are totally informal, therefore, no costs are considered for the disposal of discarded components, as non-valuable components were regularly burnt.

Scenario G4 is an evolution of scenario G3 and considers not only a technical improvement, but also the first phase of evolution from informal to formal management. It envisages: i) the supply of adequate PPE to workers; ii) banning of teenage labor; iii) a guaranteed minimum wage to employees; and iv) the disposal of non-recoverable materials into a sanitary landfill.

Scenario G5 is an evolution of scenario G4 and considers an additional step incorporating a more detailed sorting of the input materials. All of the input materials would be manually dismantled in order to extract valuable parts. Scenario G5 assesses the impacts of a workshop where there is accurate checking and sorting of the input materials. The sorting activity would separate WEEE that cannot be refurbished (and, then, has to be dismantled) from WEEE which has refurbishment potential. It is assumed that the second stream of WEEE would be treated by one specialized worker, able to repair WEEE or extract functioning spare parts. The repaired devices and the spare parts could be sold in the second-hand market that already existed in Agbogbloshie.

The main features of the six scenarios are summarized in Table 1. A mass flow analysis (MFA) was performed for each scenario using the free software STAN (subSTance flow ANalysis).

Table 1. The six proposed scenarios for WEEE management.

\begin{tabular}{|c|c|c|}
\hline Scenario & Definition & $\begin{array}{l}\text { Short Description } \\
\text { (Modifications Among the Different } \\
\text { Scenarios are Indicated by }{ }^{(*)} \text { ) }\end{array}$ \\
\hline G0 & $\begin{array}{l}\text { Informal recycling scenario } \\
\text { (current situation of informal } \\
\text { e-waste treatment) }\end{array}$ & $\begin{array}{l}\text { Manual dismantling } \\
\text { No PPE } \\
\text { No formal contracts } \\
\text { Open cable burning } \\
\text { Uncontrolled dumping of valueless parts }\end{array}$ \\
\hline G1 & Cable stripper scenario & $\begin{array}{c}\text { Manual dismantling } \\
\text { No PPE } \\
\text { No formal contracts } \\
\text { Supply of a cable stripper to avoid open cable burning }{ }^{(*)} \\
\text { Uncontrolled dumping of valueless parts }\end{array}$ \\
\hline G2 & Bicycle shredder scenario & $\begin{array}{c}\text { Manual dismantling } \\
\text { No PPE } \\
\text { No formal contracts } \\
\text { Supply of a bicycle shredder to avoid open cable burning }{ }^{(*)} \\
\text { Uncontrolled dumping of valueless parts }\end{array}$ \\
\hline G3 & Electrical shredder scenario & $\begin{array}{l}\text { Manual dismantling } \\
\text { No PPE } \\
\text { No formal contracts } \\
\text { Supply of an electrical shredder to avoid open cable burning } \\
\text { Uncontrolled dumping of valueless parts }\end{array}$ \\
\hline
\end{tabular}


Table 1. Cont.

\begin{tabular}{|c|c|c|}
\hline Scenario & Definition & $\begin{array}{l}\text { Short Description } \\
\text { (Modifications Among the Different } \\
\text { Scenarios are Indicated by }{ }^{(*)} \text { ) }\end{array}$ \\
\hline G4 & $\begin{array}{l}\text { Electrical shredder scenario }+ \text { first } \\
\text { step of formalization scenario }\end{array}$ & $\begin{array}{c}\text { Manual dismantling } \\
\text { Supply of PPE }{ }^{(*)} \\
\text { Formal contracts + ban teenager labor }{ }^{(*)} \\
\text { Supply of an electrical shredder to avoid open cable burning } \\
\text { Proper disposal of valueless parts }{ }^{(*)}\end{array}$ \\
\hline G5 & $\begin{array}{l}\text { Refurbishment and reuse }+ \text { first } \\
\text { step of formalization scenario }\end{array}$ & $\begin{array}{c}\text { Manual dismantling of } 99 \% \text { of WEEE } \\
\text { Reparation and reuse of } 1 \% \text { of the e-waste } \\
\text { Supply of PPE } \\
\text { Formal contracts + ban teenager labor } \\
\text { Supply of an electrical shredder to avoid open cable burning } \\
\text { Proper disposal of valueless parts }\end{array}$ \\
\hline
\end{tabular}

\subsection{The E-Waste Integrated Assessment Scheme (EWIAS)}

A new Integrated Assessment Scheme (IAS) was developed by Perteghella [44] to support the decision-making in waste management in low and middle-income countries, based on the sustainability concept. It was developed to investigate, design and propose new solutions in order to enhance waste management schemes in the field, in low and middle-income countries.

In this study, a specific version of the IAS was developed in order to apply it to the different scenarios. The adaption is called EWIAS (E-waste Integrated Assessment Scheme). The main difference between IAS and EWIAS is the method of calculating the economic dimension. In order to perform a WEEE management system evaluation with the EWIAS, it is necessary to understand the current practices and the stakeholders involved in the system. Then, it is possible to design and propose different scenario solutions, which can be evaluated according to the EWIAS rating score that is detailed in the next section.

\subsection{Framework of the Method and Scoring System}

The management system developed for WEEE management is not the same in every part of the world. For this reason, to apply any WEEE management framework in different countries depends on the different characteristics of each country, and the existing WEEE management systems [45-50]. In this light, a systematic procedure must be included that considers all stakeholders who have specialized knowledge and expertise in the field in order to enhance the decision-making processes. The conceptual framework adopted for this study to evaluate the different alternative scenarios is shown in Figure 2.

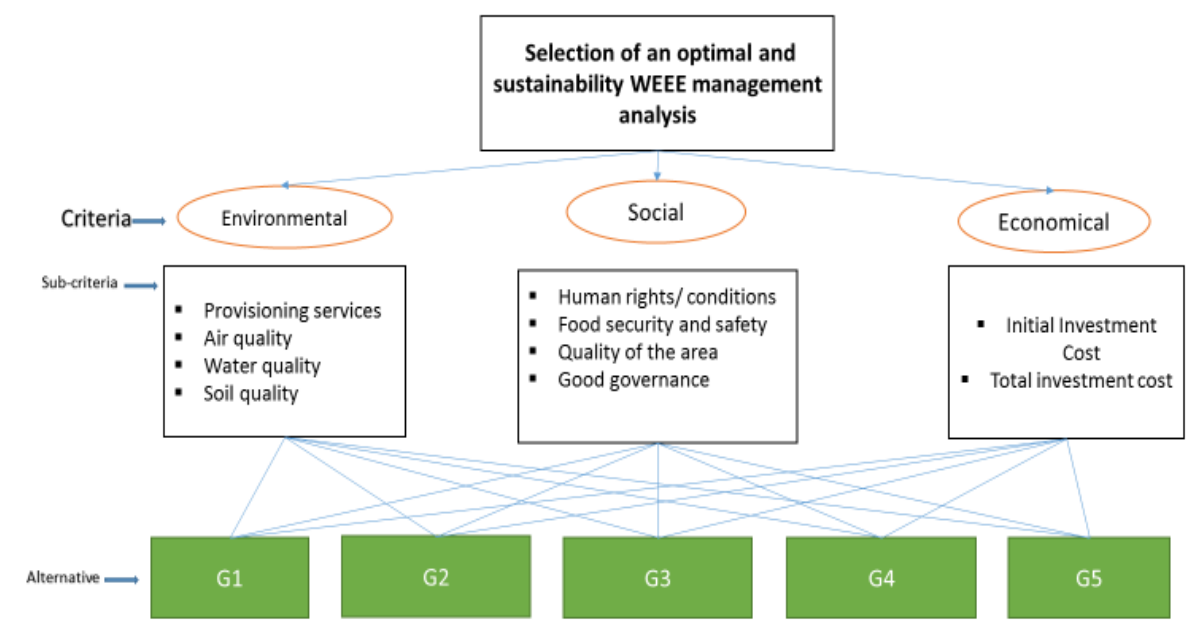

Figure 2. A conceptual framework for the evaluation of alternative waste management scenario of waste electrical and electronic equipment. 
In order to evaluate and compare the six alternative WEEE management scenarios, 10 performance criteria were selected based upon the three thematic areas of economic, social and environmental dimensions, as shown in Table 2.

Table 2. Integrated assessment scheme evaluation conceptual framework.

\begin{tabular}{|c|c|c|}
\hline Dimension & Category & Indicator \\
\hline \multirow{18}{*}{ Social } & \multirow{8}{*}{ Human rights/working conditions } & Wage level \\
\hline & & Working hours \\
\hline & & Safety working operation and safety training \\
\hline & & Equal opportunities/discrimination \\
\hline & & Employment relations \\
\hline & & Number of employees \\
\hline & & Forced labor \\
\hline & & Child labor \\
\hline & \multirow{3}{*}{ Food security and safety } & Contribution to enhance food security \\
\hline & & Contribution to enhance food safety \\
\hline & & $\begin{array}{c}\text { Impact on visual amenity/visual pollution } \\
\text { Odor }\end{array}$ \\
\hline & \multirow{4}{*}{ Quality of the area } & Enjoyment of living in the area \\
\hline & & Fear of crime \\
\hline & & Public health \\
\hline & & Rule of law \\
\hline & \multirow[t]{3}{*}{ Good governance } & Holistic management \\
\hline & & Participation \\
\hline & & Food and fiber \\
\hline \multirow[t]{17}{*}{ Environmental } & \multirow[t]{3}{*}{ Provisioning services } & Ornamental resources \\
\hline & & Freshwater \\
\hline & & GHGs emissions \\
\hline & \multirow{5}{*}{ Air quality } & Non-GHGs emissions \\
\hline & & Air quality regulation \\
\hline & & Climate regulation \\
\hline & & Organic pollutants \\
\hline & & Inorganic pollutants \\
\hline & \multirow{4}{*}{ Water quality } & Microbiological pollutants \\
\hline & & Water cycling and regulation \\
\hline & & Water purification and nutrient cycling \\
\hline & & Waterborne pest and diseases \\
\hline & & Organic pollutants \\
\hline & & Inorganic pollutants \\
\hline & Soil quality & Erosion regulation \\
\hline & & Nutrient cycling and soil formation \\
\hline & & Soil-borne pest and diseases \\
\hline \multirow{2}{*}{ Economic } & & Initial investment cost (US\$) \\
\hline & & Total waste management cost (US\$/year) \\
\hline
\end{tabular}

The social and environmental dimensions were evaluated using a scoring system (Supplementary Material SM-A), whereas the economic dimension was evaluated in a quantitative way. Based on Perteghella [44], the expert scores were categorized on a five-interval scale with respect to the environmental and social dimensions (Table 3). The scores were developed and agreed by five experts who all had over 10 years' experience and were from a range of relevant fields (i.e., environmental engineering, sustainability, economy, ecology and sociology). The scores were then discussed with the main local beneficiaries in Agbogbloshie (i.e., representatives of municipality, local environmental associations, directors, workers and owners of workshops treating WEEE), and any necessary amendments made based on their feedback.

Firstly, the mean values of each interval $(0.4,1.2,2,2.8,3.6)$ were assigned an indicator $\mathrm{I}_{\mathrm{ij}}$ according to their description (Supplementary Material SM-A). According to Perteghella [44], the mean value was used because it gave the most representative point of each category. The average indicator's value $\mathrm{C}_{\mathrm{j}}$ defined the score of the category:

$$
\mathrm{C}_{\mathrm{j}}=\sum \mathrm{I}_{\mathrm{ij}} / \mathrm{n}_{\mathrm{ij}}
$$

where $n_{i j}$ represents the number of indicators for the specific category. 
$\mathrm{NC}_{\mathrm{j}}$ represents the normalized category value in order to comply with the $0-4$ qualitative rate range:

$$
\mathrm{NC}_{\mathrm{j}}=\mathrm{C}_{\mathrm{j}} \frac{4}{3.6}
$$

The normalized categories' average values $\mathrm{NC}_{\mathrm{j}}$ define the final score for the environmental and the social dimensions:

$$
\mathrm{D}=\sum \mathrm{NC}_{\mathrm{i}} / \mathrm{n}_{\mathrm{i}}
$$

where $n_{j}$ represents the number of categories in each dimension.

Table 3. The scoring range for the social and environmental dimensions.

\begin{tabular}{cc}
\hline Qualitative Rate & Qualitative Rate Score \\
\hline Very low or negligible & $0-0.79$ \\
Low & $0.8-1.59$ \\
Moderate & $1.6-2.39$ \\
High & $2.4-3.19$ \\
Very high & $3.2-4$ \\
\hline
\end{tabular}

With regards to the economic dimension, a simple cost-accounting concerning all the costs and revenues that could arise from the scenarios was developed to easily present understandable results to local stakeholders. In this way, it was possible to outline what the costs and benefits are linked to the activity. Direct costs, general and indirect costs, maintenance costs and fixed costs were the main items considered and calculated for each proposed solution. These costs define the two indicators that describe the economic dimension for each scenario, namely the initial investment costs and total waste management costs.

Direct costs describe all the specific costs that are directly linked with goods produced or services provided. For the waste management system, the operators' salaries (i.e., WEEE collectors and dismantlers, copper cable burners, etc.), fuel and electricity consumption (working tools and electric equipment consumption, such as cable shredders, etc.) are accounted for. General and indirect costs [51] are not directly accountable to a goods production process or service provision. This cost category entails various different items such as administrative staff, security costs, telephone, business travel, internet, social spending, taxes, insurance, and advertisements. Based on the Italian Ministry of Finance [51], the general and indirect costs were estimated to be $15 \%$ of the direct costs. Maintenance costs entail the ordinary expenditures that have to be supported in order to provide the necessary maintenance operations to safeguard and extend the lifespan functionality of the equipment, means of work, civil structures and buildings. As reported by Vaccari et al. [52], the equipment and means of work maintenance costs can be estimated to be equal to $5 \%$ of the direct costs. Fixed costs include costs for goods production or services provision, as well as depreciation costs, which represent equipment, means of work and building initial investment costs distribution during the operative working years. The depreciation costs were calculated by the straight-line depreciation method (i.e., depreciation equals the initial investment cost of each item divided by its lifespan). In addition to the aforementioned costs, the revenues coming from the sale of valuable components (copper, aluminum, etc.) were considered in order to have a full economic balance/overview concerning each waste management solution. Table 4 reports all the items that were taken into account in order to perform the economic evaluation. Then, all these item costs and revenues were used in order to define the final initial investment cost and the total waste management cost. Unitary costs, revenues and further data used for the economic evaluation are listed in Supplementary Material SM-B. 
Table 4. Items considered to determine the total WEEE management costs.

\begin{tabular}{cc}
\hline Item & Scenario Cost Item (US\$/Year) \\
\hline A & FIXED COSTS (Rent of the workshop, equipment purchase, etc.) \\
B & DIRECT COSTS (Operator salaries and energy consumption) \\
C & GENERAL AND INDIRECT COSTS $(15 \%$ direct costs) \\
D & MAINTENANCE COSTS (5\% direct costs) \\
E & REVENUES (Secondary raw materials sale) \\
F & TOTAL WEEE MANAGEMENT COSTS (A+B+C+D+E) \\
\hline
\end{tabular}

\section{Results}

\subsection{Material Flow Analyses of the Scenarios}

Figure 3 shows the mass flow of the WEEE entering the workshop and the recyclables/wastes exiting. Polluting steps, such as uncontrolled cable burning, and open dumping are highlighted in orange. Figure 3 shows that of the 163.8 tons of WEEE collected yearly, some $72 \mathrm{t}$ were estimated to be recoverable as metals (i.e., iron and aluminum).

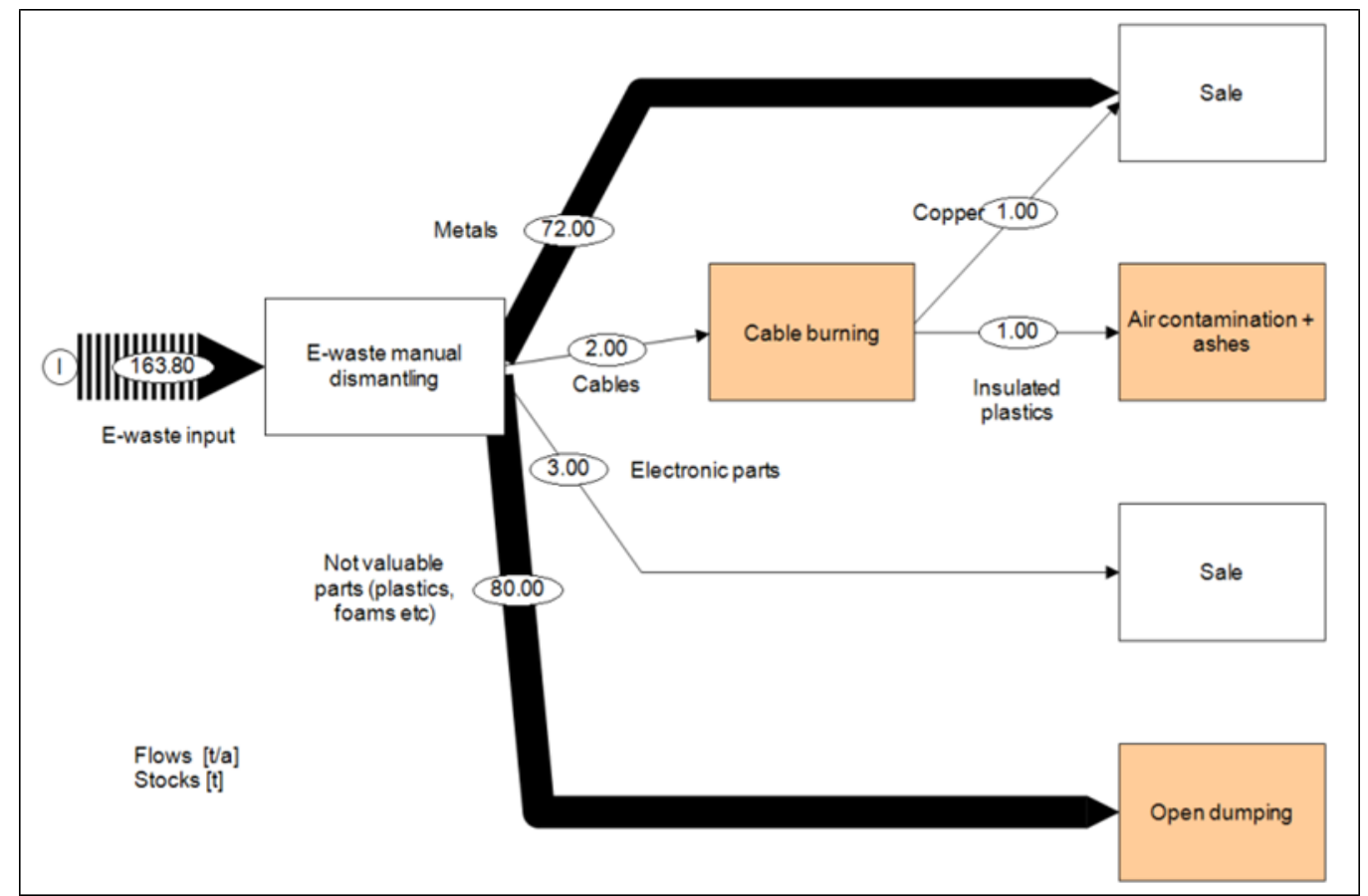

Figure 3. Mass flow scheme of the current situation in the study area (Scenario G0).

The mass flows of the other scenarios (i.e., from G1 to G5) are shown in Supplementary Material SM-C.

\subsection{EWIAS Applied to the Study Area}

Figure 4a compares the initial investment costs of each scenario. The first three scenarios (i.e., G0, G1, G2) have relatively limited investment costs of lower than US\$1,200. However, there were estimated costs of between US $\$ 3,200$ - 4,000 for scenarios G3 - G5, where more complex machines would be utilized. 


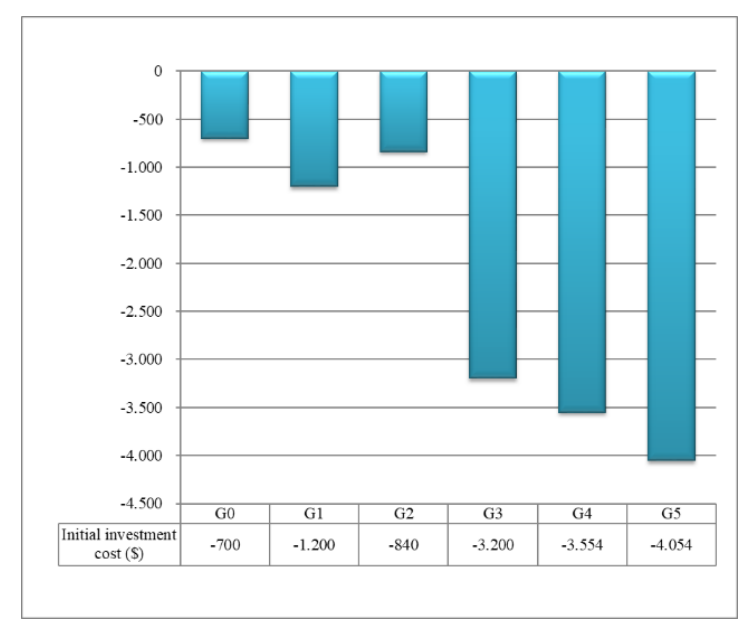

(a)

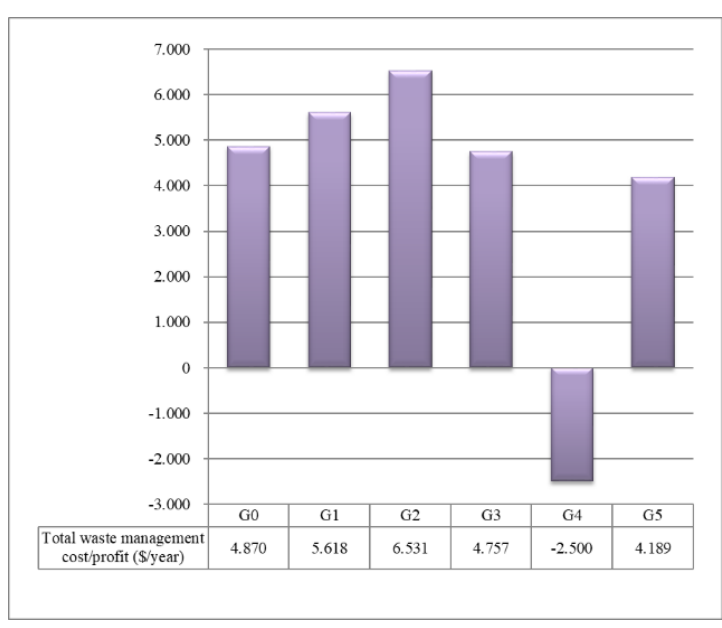

(b)

Figure 4. Economic dimension assessment: a) initial investment cost; b) total waste management cost/profit.

On the other hand, Figure $4 \mathrm{~b}$ shows that the first four scenarios (G0, G1, G2, G3), should realize a profit of up to US $\$ 6,500 / y$. The formalization of the activity requires much higher management costs, due mainly to the landfilling of the non-recoverable materials. However, the improvement in the workshop activities, with the introduction of repair and reuse as in scenario G5, where the repaired devices and the spare parts are sold in a second-hand market, should result in a profit of around US\$4,200.

Figure 5 summarizes the assessment of the social dimension. The scores allocated to each social indicator are reported in Supplementary Material SM-D. Scenario G0 has the lowest score of 2.0. Whereas, the evaluation for the G1, G2 and G3 scenarios (which do not have any formalization), are equal to 2.1, 2.4 and 2.5, respectively, for G4, it is 3.2. Scenario G5 has the highest evaluation, equal to 3.4, and the difference between G4 and G5 is minimal.

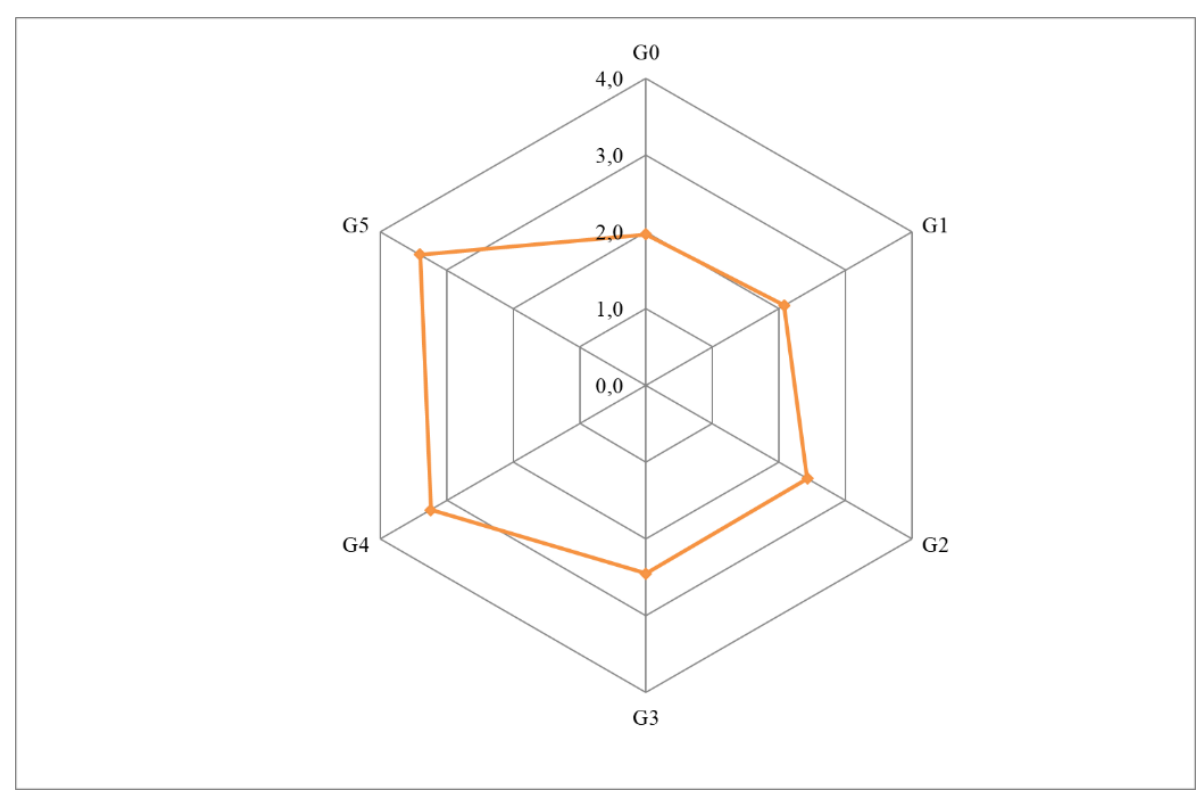

Figure 5. Social dimension assessment. 
Figure 6 summarizes the assessment of the environmental dimension. The scores allocated to each social indicator are reported in Supplementary Material SM-E. Scenario G0 has the lowest score, equal to 0.6 , mainly due to the air quality evaluation, which is equal to 0.4 , and it is directly connected with uncontrolled cable burning. The soil quality and water quality are also very low because the unwanted components are burnt and disposed of into a dumpsite. The environmental evaluation increased in the scenarios, as G1, G2, G3, G4, and G5 were 1.0, 1.1, 1.3, 2.2 and 3.0, respectively. Globally, Figure 6 illustrates an enhancement in the environmental dimension moving from the G0 scenario (the worst from a technical point of view) to G5, which is the best with respect to technical waste treatments and processes.

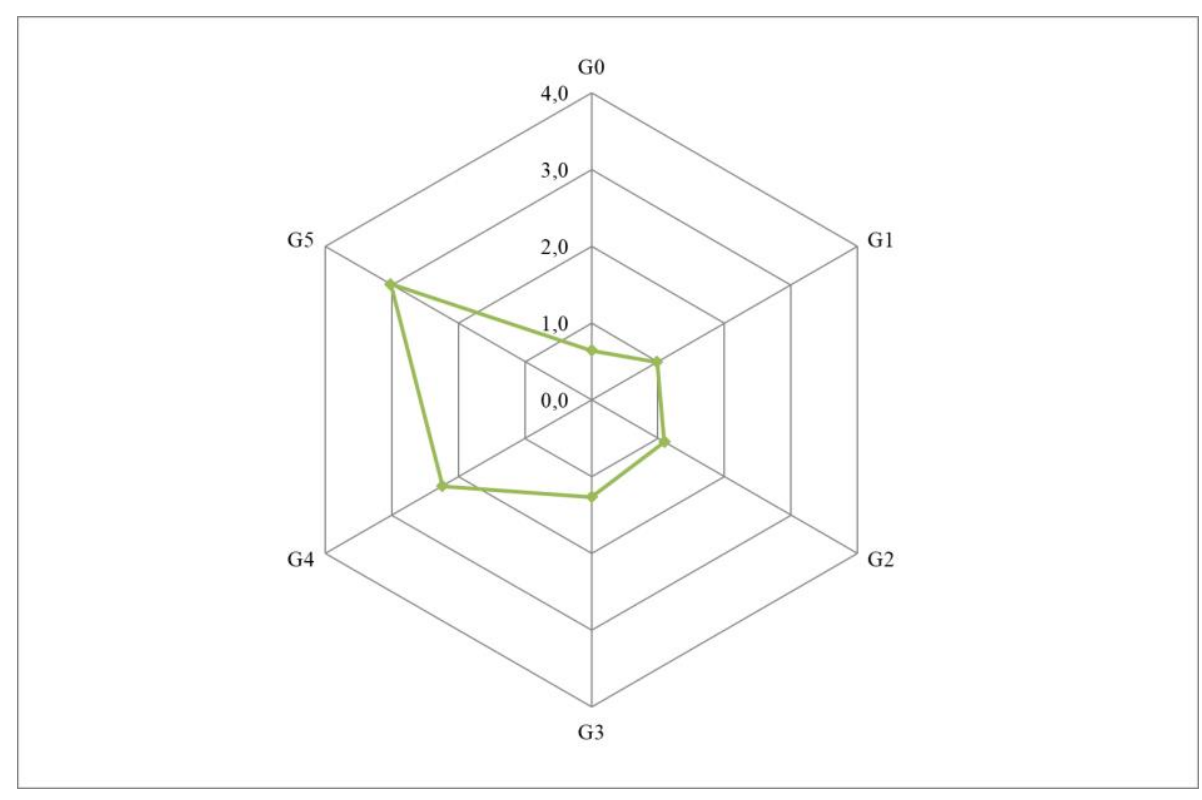

Figure 6. Environmental dimension assessment.

\section{Discussion}

One of the key challenges in effectively managing solid waste, particularly in developing countries, is the selection of appropriate, bespoken options. Using a workshop managing WEEE in Agbogbloshie in Ghana as the case study, this research employed EWIAS (a specific version of IAS) to assess the economic, environmental and social impacts in the study area, using six scenarios.

Approximately 44\% (72/163.8 tons) of the WEEE collected annually was estimated to be recoverable as metals, primarily iron and aluminum. Thus, there is good potential for not only the recovery of valuable materials but also for revenues to be earned from sales. The first three scenarios (i.e., G0, G1, G2) had investment costs of less than US $\$ 1,200$, while there were estimated costs of between US\$3,200 4000 for scenarios G3 - G5, due to more complex machines being utilized. The first four scenarios (G0, G1, G2, G3), should realize a profit of up to US\$6,500/y, with G5 realizing a profit of around US\$4,200 (Figure 4A,B). Thus, generally, as the level of formalization of the processes increased, the potential profits also increase (Figure 4A,B). The lower profitability for scenario G4, as compared to G3, is due to the required input costs, for example, to supply adequate PPE to workers, and pay a guaranteed minimum wage.

The low social dimension score for G0 (Figure 5), is because the site had high visual pollution, odor, and a high crime rate, coupled with a high health risk linked to the inappropriate WEEE management practices. In fact, levels of dibenzo-p-dioxins and dibenzofurans in the blood of informal WEEE recycling workers in Agbogbloshie were demonstrated to be significantly higher than those found in a control group of people of Accra living without direct exposure to WEEE dumps/recycling sites and activities [53]. Moreover, evidence of much higher concentrations of organic and inorganic pollutants 
in WEEE recycling workers, compared to a control population, were found also in China [54] and India [55]. Such high concentrations can lead to high toxic risk $(>1)$ and carcinogenic risk $\left(>10^{-5}\right)$ as demonstrated by various studies [56,57]. The governance systems in G0 are low, which justifies the poor quality of the provided WEEE service. With improvements in the management of the WEEE, including replacing the burning of cables with cable stripping and shredding, the social dimension score increases. Moreover, an additional enhancement of the social dimension was observed in scenario G4 with the first step of formalization. It included the supply of adequate PPE to workers (e.g., dust masks, safety glasses, gloves and shoes), the banning of teenage labor and the guaranteeing of a minimum wage to employees. In addition, the unwanted materials are not burnt, but rather are disposed of in a sanitary landfill. The slight increase for G5 is due to an improvement in the working conditions because this scenario considers the refurbishment of a small part of WEEE, and the workers who perform this kind of activity usually have a higher educational level and receive a higher salary.

From Figure 6, it is evident that there are two steps required for improvement in the environmental scores. The first is connected with the substitution of open cable burning with an alternative, as is the case in G1, G2, and G3, which all utilize cable stripping or shredding. The stripping and shredding technologies result in an improvement of the air quality values, which were $0.9,1.3$ and 2.0, respectively. The second step of improvement is evident in scenarios G4 and G5, and is directly connected with the first step of formalization, which includes effective disposal of the discarded components into a sanitary landfill. This second step produces an improvement not only in the air quality but also in all of the environmental categories (i.e., the provisioning service, water quality, and soil quality). G5 has the highest value because it reduces the quantity of discarded parts due to the refurbishment of a small part $(1 \%)$ of the WEEE input.

The EWIAS approach was able to effectively evaluate the social, economic and environmental conditions associated with managing WEEE in Agbogbloshie. Similar previous studies utilized a multi-criteria approach, incorporating environmental, economic and social factors [37-39]. It is an integrated assessment scheme, which includes all stakeholders within the community to enhance the decision-making processes. However, there are some limitations. For example, the evaluation is based on an average workshop. There were also some assumptions made, for example, in the costs utilized. Its effective application also depends on an understanding of local conditions. Nevertheless, EWIAS can serve as a useful tool to inform the decision-making process in order to promote more effective and sustainable management of WEEE and other wastes.

\section{Conclusions}

Quantities of WEEE are rising globally, and are predicted to continue to grow. However, its effective management in developing countries, even in the case study country of Ghana where legislation has been enacted, remains limited. This issue has significant implications due to the environmental, social and economic impacts.

In this study, a novel approach using the tool EWIAS, was used to identify and evaluate the key social, environmental and economic factors facing employees in a workshop managing WEEE in Agbogbloshie, and to suggest recommendations for improvement. The results made clear that the best solution was the evolution from informal to formal management of WEEE, with workers provided with $\mathrm{PPE}$, and the introduction of refurbishment activities, with the sale of components in the second-hand market. A less preferable option, that is simpler and requires much lower initial investment costs, is the introduction of manual cable stripping or shredding to avoid open cable burning, thus reducing the health and environmental impacts due to the combustion emissions.

This is a very limited case study and thus, the results should be viewed with some caution. Nevertheless, they do suggest that with reasonably 'limited' investment, it is possible to address the environmental, social and public health challenges faced in effectively managing WEEE within communities in developing countries such as Ghana. In addition, they also suggest, that with the end-markets in place, that these initiatives can be self-sustaining and indeed, profitable. There is a need 
for the utilization of trials of schemes, funded perhaps by international agencies, to further evaluate the potential of the scenarios developed in this study. These trials should incorporate the provision of training, perhaps the donation of the supply of equipment, and should involve all key stakeholders in the community. With respect to the EWIAS, evidently, it was able to facilitate the development of the scenarios. Crucially, it also enabled involvement of experts and those in the community in the development of these scenarios that were bespoke for the community. While further trials in other contexts would be required, it therefore could serve as a useful tool to inform the decision-making processes for the management of WEEE and other waste streams in developing countries.

Supplementary Materials: The following are available online at http:/www.mdpi.com/2071-1050/12/8/3191/s1, SM-A: Rating system for social and environmental dimensions, SM-B: Unitary cost, revenues and further data used for the economic evaluation, SM-C: Mass flow of Scenarios G1-G5, SM-D: Social dimension evaluation: Bestowed scores, SM-E: Environmental dimension evaluation: Bestowed scores.

Author Contributions: F.Z. and M.V. developed the methodological concept and data analysis. F.Z. collected the data. M.B. and T.T. assisted in designing the framework and supported data analysis. M.V. provided overall guidance and supervision of this research. T.A.; T.T. and M.V. wrote the manuscript. All authors have read and agreed to the published version of the manuscript.

Funding: This research received no external funding.

Conflicts of Interest: The authors declare that they have no conflict of interest.

\section{References}

1. Achillas, C.; Vlachokostas, C.; Aidonis, D.; Moussiopoulos, N.; Iakovou, E.; Banias, G. Optimising reverse logistics network to support policymaking in the case of electrical and electronic equipment. Waste Manag. 2010, 30, 2592-2600. [CrossRef] [PubMed]

2. Ongondo, F.O.; Williams, I.D.; Cherrett, T.J. How are WEEE doing? A global review of the management of electrical and electronic wastes. Waste Manag. 2011, 31, 714-730. [CrossRef] [PubMed]

3. Tsydenova, O.; Bengtsson, M. Chemical hazards associated with treatment of waste electrical and electronic equipment. Waste Manag. 2011, 31, 45-58. [CrossRef] [PubMed]

4. Herat, S. Sustainable Management of Electronic Waste (e-Waste). Clean-Soil Air Water 2007, 35, $305-310$. [CrossRef]

5. Herat, S. Environmental impacts and use of brominated flame retardants in electrical and electronic equipment. Environmentalist 2008, 28, 348-357. [CrossRef]

6. Cui, J.; Zhang, L. Metallurgical recovery of metals from electronic waste: A review. J. Hazard. Mater. 2008, 158, 228-256. [CrossRef]

7. Liu, X.; Tanaka, M.; Matsui, Y. Electrical and electronic waste management in China: Progress and the barriers to overcome. Waste Manag. Res. 2006, 24, 92-101. [CrossRef]

8. Hischier, R.; Wäger, P.; Gauglhofer, J. Does WEEE recycling make sense from an environmental perspective? The environmental impacts of the Swiss take-back and recycling systems for waste electrical and electronic equipment (WEEE). Environ. Impact Assess. Rev. 2005, 25, 525-539. [CrossRef]

9. Gamberini, R.; Gebennini, E.; Manzini, R.; Ziveri, A. On the integration of planning and environmental impact assessment for a WEEE transportation network-A case study. Res. Conserv. Recycl. 2010, 54, 937-951. [CrossRef]

10. Baldé, C.P.; Wang, F.; Kuehr, R.; Huisman, J. The Global E-waste Monitor-2017; United Nations University (UNU): Bonn, Germany; International Telecommunication Union (ITU): Geneva, Switzerland; International Solid Waste Association (ISWA): Vienna, Austria, 2019; ISBN 978-92-808-9053-2.

11. Robinson, B.H. E-waste: An assessment of global production and environmental impacts. Sci. Total Environ. 2009, 408, 183-191. [CrossRef]

12. Vaccari, M.; Vinti, G.; Cesaro, A.; Belgiorno, V.; Salhofer, S.; Dias, M.I.; Jandric, A. WEEE treatment in developing countries: Environmental pollution and health consequences-An overview. Int. J. Environ. Res. Public Health 2019, 16, 1595. [CrossRef] [PubMed] 
13. Cesaro, A.; Belgiorno, V.; Gorrasi, G.; Viscusi, G.; Vaccari, M.; Vinti, G.; Jandric, A.; Dias, M.I.; Hursthouse, A.; Salhofer, S. A relative risk assessment of the open burning of WEEE. Environ. Sci. Pollut. Res. 2019, 26, 11042-11052. [CrossRef] [PubMed]

14. Cesaro, A.; Belgiorno, V.; Vaccari, M.; Jandric, A.; Chung, T.D.; Dias, M.I.; Hursthouse, A.; Salhofer, S. A device-specific prioritization strategy based on the potential for harm to human health in informal WEEE recycling. Environ. Sci. Pollut. Res. 2018, 25, 683-692. [CrossRef] [PubMed]

15. Sthiannopkao, S.; Wong, M.H. Handling e-waste in developed and developing countries: Initiatives, practices, and consequences. Sci. Total Environ. 2013, 463, 1147-1153. [CrossRef] [PubMed]

16. Bahers, J.B.; Kim, J. Regional approach of waste electrical and electronic equipment (WEEE) management in France. Res. Conserv. Recycl. 2018, 129, 45-55. [CrossRef]

17. Premalatha, M.; Abbasi, T.; Abbasi, S.A. The generation, impact, and management of e-waste: State of the art. Crit. Rev. Environ. Sci. Technol. 2014, 44, 1577-1678. [CrossRef]

18. Oguchi, M.; Murakami, S.; Sakanakura, H.; Kida, A.; Kameya, T.A. A preliminary categorization of end-of-life electrical and electronic equipment as secondary metal resources. Waste Manag. 2011, 31, 2150-2160. [CrossRef]

19. Oguchi, M.; Sakanakura, H.; Terazono, A.; Takigami, H. Fate of metals contained in waste electrical and electronic equipment in a municipal waste treatment process. Waste Manag. 2012, 32, 96-103. [CrossRef]

20. Schlummer, M.; Gruber, L.; Mäurer, A.; Wolz, G.; Van Eldik, R. Characterisation of polymer fractions from waste electrical and electronic equipment (WEEE) and implications for waste management. Chemosphere 2007, 67, 1866-1876. [CrossRef]

21. Moussiopoulos, N.; Karagiannidis, A.; Papadopoulos, A.; Achillas, C.; Antonopoulos, I.; Perkoulidis, G.; Vlachos, D.; Vlachokostas, C. Transportation cost analysis of the Hellenic system for alternative management of Waste Electrical and Electronic Equipment. Int. J. Environ. Waste Manag. 2012, 10, 70-89. [CrossRef]

22. Jang, Y.C.; Kim, M. Management of used \& end-of-life mobile phones in Korea: A review. Res. Conserv. Recycl. 2010, 55, 11-19.

23. Batinic, B.; Vaccari, M.; Savvilotidou, V.; Kousaiti, A.; Gidarakos, E.; Marinkovic, T.; Fiore, S. Applied WEEE pre-treatment methods: Opportunities to maximizing the recovery of critical metals. Glob. NEST J. 2018, 20, 706-711.

24. Savvilotidou, V.; Kousaiti, A.; Batinic, B.; Vaccari, M.; Kastanaki, E.; Karagianni, K.; Gidarakos, E. Evaluation and comparison of pre-treatment techniques for recovering indium from discarded liquid crystal displays. Waste Manag. 2019, 87, 51-61. [CrossRef] [PubMed]

25. Dias, P.; Bernardes, A.M.; Huda, N. Ensuring best E-waste recycling practices in developed countries: An Australian example. J. Clean. Prod. 2019, 209, 846-854. [CrossRef]

26. Zeng, X.; Gong, R.; Chen, W.Q.; Li, J. Uncovering the recycling potential of “New” WEEE in China. Environ. Sci. Technol. 2016, 50, 1347-1358. [CrossRef] [PubMed]

27. Quaye, W.; Akon-Yamga, G.; Daniels, C.; Ting, B.; Asante, A. Transformation Innovation Learning History of Ghana's E-Waste Management System; University of Sussex: Falmer, UH, USA, 2019. Available online: http://www.tipconsortium.net/wp-content/uploads/2019/10/Ghana_-TILH_Oct2019_final.pdf (accessed on 31 January 2020).

28. Hector, M. Toxic Trade: E-Waste Disposal and Environmental Governance in West Africa; Stellenbosch University: Stellenbosch, South Africa, 2017.

29. Atiemo, S.M.; Ofosu, F.G.; Aboh, I.K.; Kuranchie-Mensah, H. Assessing the heavy metals contamination of surface dust from waste electrical and electronic equipment (e-waste) recycling site in Accra, Ghana. Res. J. Environ. Earth Sci. 2012, 4, 605-611.

30. Klundert, A.; Anschütz, J. Tools for Decision Makers: Experiences from the Urban Waste Expertise Programme (1995-2001); Integrated Sustainable Waste Management, The Concept: Waste, Gouda, The Netherlands, 2001.

31. Nartey, K.V. Environmental and Health Impacts of Informal E-Waste Recycling in Agbogbloshie, Accra, Ghana: Recommendations for Sustainable Management. Master's Thesis, University of Bonn, Bonn, Germany, 2016.

32. Amoyaw-Osei, Y.; Agyekum, O.O.; Pwamang, J.A. Informal E-Waste Management in Ghana-Economic Impacts and Feasibility of International Recycling Co-Operations; Environmental Protection Agency: Accra, Ghana, 2011. 
33. Caravanos, J.; Clark, E.; Fuller, R.; Lambertson, C. Assessing Worker and Environmental Chemical Exposure Risks at an e-Waste Recycling and Disposal Site in Accra, Ghana. J. Health Pollut. 2011, 1, 16-25. [CrossRef]

34. Oteng-Ababio, M.; Owusu, G.; Chama, M. Intelligent enterprise: Wasting, valuing and re-valuing waste electrical and electronic equipment. Geogr. J. 2016, 182, 265-275. [CrossRef]

35. Manhart, S.P.A. Socio-Economic Assessment and Feasibility Study on Sustainable E-Waste Management in Ghana; Öko-Institut e.V.: Freiburg, Germany, 2011.

36. Cherubini, F.; Bargigli, S.; Ulgiati, S. Life cycle assessment (LCA) of waste management strategies: Landfilling, sorting plant and incineration. Energy 2009, 34, 2116-2123. [CrossRef]

37. Morrissey, A.; Browne, J. The application of multicriteria decision making techniques in the assessment of waste management strategies. WIT Trans. Ecol. Environ. 2002, 56. [CrossRef]

38. Robinson, K.C.; Phillips McDougall, P. Entry barriers and new venture performance: A comparison of universal and contingency approaches. Strateg. Manag. J. 2001, 22, 659-685. [CrossRef]

39. Hulzebos, E.; Gunnarsdottir, S.; Rila, J.P.; Dang, Z.; Rorije, E. An Integrated Assessment Scheme for assessing the adequacy of (eco) toxicological data under REACH. Toxicol. Lett. 2010, 198, 255-262. [CrossRef] [PubMed]

40. Kumar, A.; Holuszko, M.; Espinosa, D.C.R. E-waste: An overview on generation, collection, legislation and recycling practices. Res. Conserv. Recycl. 2017, 122, 32-42. [CrossRef]

41. Parajuly, K.; Habib, K.; Liu, G. Waste electrical and electronic equipment (WEEE) in Denmark: Flows, quantities and management. Res. Conserv.Recycl. 2017, 123, 85-92. [CrossRef]

42. Ferronato, N.; Rada, E.C.; Portillo, M.A.; Cioca, L.I.; Ragazzi, M.; Torretta, V. Introduction of the circular economy within developing regions: A comparative analysis of advantages and opportunities for waste valorization. J. Environ. Manag. 2019, 230, 366-378. [CrossRef]

43. Pérez, R.F.F. Tools for Informal E-Waste Recyclers in Agbogbloshie, Ghana. MSc Practising Sustainable Development-ICT4D. Master's Thesis, Royal Holloway University of London, Egham, UK, 2014.

44. Perteghella, A. An Integrated Assessment Scheme Supporting Decision Making in Waste Management in Low and Middle-Income Countries. Ph.D. Thesis, University of Brescia, Brescia, Italy, 2015.

45. Cooper, T. WEEE, WEEE, WEEE, WEEE, all the way home? An evaluation of proposed electrical and electronic waste legislation. Eur. Environ. 2000, 10, 121-130. [CrossRef]

46. Manomaivibool, P. Extended producer responsibility in a non-OECD context: The management of waste electrical and electronic equipment in India. Res. Conserv. Recycl. 2009, 53, 136-144. [CrossRef]

47. Agamuthu, P.; Kasapo, P.; Nordin, N.A.M. E-waste flow among selected institutions of higher learning using material flow analysis model. Res. Conserv. Recycl. 2015, 105, 177-185. [CrossRef]

48. Pérez-Belis, V.; Bovea, M.; Gómez, A. Waste electric and electronic toys: Management practices and characterisation. Res. Conserv. Recycl. 2013, 77, 1-12. [CrossRef]

49. Achillas, C.; Vlachokostas, C.; Moussiopoulos, N.; Banias, G. Decision support system for the optimal location of electrical and electronic waste treatment plants: A case study in Greece. Waste Manag. 2010, 30, 870-879. [CrossRef]

50. Rousis, K.; Moustakas, K.; Malamis, S.; Papadopoulos, A.; Loizidou, M. Multi-criteria analysis for the determination of the best WEEE management scenario in Cyprus. Waste Manag. 2008, 28, 1941-1954. [CrossRef] [PubMed]

51. Ministero delle Finanze. Linee Guida per la Redazione del Piano Finanziario e per L'elaborazione Delle Tariffe; Ministero delle Finanze: Rome, Italy, 2013.

52. Vaccari, M.; Di Bella, V.; Vitali, F.; Collivignarelli, C. From mixed to separate collection of solid waste: Benefits for the town of Zavidovići (Bosnia and Herzegovina). Waste Manag. 2012, 33, 277-286. [CrossRef] [PubMed]

53. Wittsiepe, J.; Fobil, J.N.; Till, H.; Burchard, G.D.; Wilhelm, M.; Feldt, T. Levels of polychlorinated dibenzo-p-dioxins, dibenzofurans (PCDD/Fs) and biphenyls (PCBs) in blood of informal e-waste recycling workers from Agbogbloshie, Ghana, and controls. Environ. Int. 2015, 79, 65-73. [CrossRef]

54. Zhang, T.; Ruan, J.; Zhang, B.; Lu, S.; Gao, C.; Huang, L.; Bai, X.; Xie, L.; Gui, M.; Qiu, R. Heavy metals in human urine, foods and drinking water from an e-waste dismantling area: Identification of exposure sources and metal-induced health risk. Ecotoxicol. Environ. Saf. 2019, 169, 707-713. [CrossRef]

55. Eguchi, A.; Nomiyama, K.; Devanathan, G.; Subramanian, A.; Bulbule, K.A.; Parthasarathy, P.; Takahashi, S.; Tanabe, S. Different profiles of anthropogenic and naturally produced organohalogen compounds in serum from residents living near a coastal area and e-waste recycling workers in India. Environ. Int. 2012, 47, 8-16. [CrossRef] 
56. Yu, Y.; Zhu, X.; Li, L.; Lin, B.; Xiang, M.; Zhang, X.; Chen, X.; Yu, Z.; Wang, Z.; Wan, Y. Health implication of heavy metals exposure via multiple pathways for residents living near a former e-waste recycling area in China: A comparative study. Ecotoxicol. Environ. Saf. 2019, 169, 178-184. [CrossRef]

57. Singh, M.; Thind, P.S.; John, S. Health risk assessment of the workers exposed to the heavy metals in e-waste recycling sites of Chandigarh and Ludhiana, Punjab, India. Chemosphere 2018, 203, 426-433. [CrossRef]

(C) 2020 by the authors. Licensee MDPI, Basel, Switzerland. This article is an open access article distributed under the terms and conditions of the Creative Commons Attribution (CC BY) license (http://creativecommons.org/licenses/by/4.0/). 